\title{
The Philosophical Revitalization of
} Malay Motif Ornament in the Design of Woven Gedebong (Catri N Art, Rimbang Sekampung Village)

\section{Juliana and Hetty Zaharani}

Universitas Potensi Utama (UPU), Medan, Indonesia

\section{Abstract}

This research aimed to revitalize the phylosophy of Malay motif ornament in the design of woven gedebong by optimalization potency of Catri N Art creative industry, Rimbang Sekampung Village. This research used a qualitative descriptive method with ethnographic approach. The data were collected through observation, interview and documentation. The research was conducted with doing the development of Catri $\mathrm{N}$ Art creative industry in the realization of the production and marketing systems to createthe woven gedebong based on Malay motif ornaments. There were four

Corresponding Author:

Juliana

juliana@potensi-utama.ac.id

Received: 1 July 2019

Accepted: 18 July 2019

Published: 31 July 2019

Publishing services provided by

Knowledge E

(c) Juliana and Hetty

Zaharani. This article is

distributed under the terms of

the Creative Commons

Attribution License, which

permits unrestricted use and

redistribution provided that the

original author and source are

credited.

Selection and Peer-review under the responsibility of the AICLL 2019 Conference Committee. motifs used in the design of woven gedebong, they wereflora, fauna, natural and wajik motifs. Firstly, fllora motifs ornaments are from flowers, florets, leaves, fruits, roots. Secondly, fauna motifs ornaments are from poultry animals such as bird, duck, chicken, reptile animals such as snake, dragon, wild animals such as lion, tiger, insects such as bee, butterfly, grasshopper, aquatic animals such as fish, eel. Thirdly, outer space such as moon, star, sun, cloud, and lastly, Wajik such as the alquran ayats. The philosophical local wisdom values of Malay ornaments are the values of taqwa (faith) to Allah, harmony, wisdom, heroic, affection, fertility, self-knowing, responsibility. The result showed that the optimization of Catri N Art potency to produce woven gedebong based on Malay motif ornaments can be useful to revitalize the Malay philosophical of local wisdom values and also to increase creative industry.

Keywords: Revitalisasion, Phylosophy, Malay ornament, Woven Gedebong

\section{Introduction}

The development of tourism potency based on local wisdom has succeeded in increasing the attractiveness of tourists visiting Indonesia as a favorite tourist destination. This is the data from the statistics center institute of Medan which states that the potency of tourism and the best tourist destinations of North Sumatra has increased the number 
tourist arrivals to North Sumatra in 2017 increased by 270,792 people and increased to 15.96 percent compared to last year. (Utara, 2010: 25).

For this reason, a strategy is needed to maintain the success of the North Sumatra tourism sector. One of them is through fostering creative industry to develop tourism potency to create souvenirs of local cultural value as an attraction for tourists to remain loyal to visit North Sumatra. One of the creative industries that can be fostered to support this government program is Catri N Art small creative industry, Rimbang Sekampung Village. This creative industry has the potency of human resources and natural resources because it is empowered to improve the economy of the local community in producing cultural value tourism works. Souvenirs that will be cultivated in the form of woven gedebong based Malay ornament such as bag, pencil case, kleenex box, cookie box, slipper, ashtray, skewer, so that the woven gedebong based on Malay ornament can be used as a unique souvenir of Rimbang Sekampung Village and also as an attraction for tourists to visit the value of local wisdom in the local community. Thus, this village is expected to be used as a place for developing local wisdom-based tourism potency and increasing community productivity to become independent entrepreneurs as a form of concrete action to revitalize the value of local wisdom in improving the economy of the community( Juliana \& Fatimah, 2018:131).

However, based on the facts in the field, this creative industry has still constrained by the quality of human resources and the quality of products that are of low selling value. In fact, the quality of human resources is the main capital in economic development in each region. For this reason, a strategy is needed to overcome this problem. One of the strategies is to empower and optimize every potency resource through developing the SMME sector in the form of fostering creative industry groups with entrepreneurship training such as developing and creating innovative and good quality products which have local cultural values to improve the quality of independent, creative and innovative entrepreneurial human resources (Juliana \& Fatimah, 2018:395).

Therefore, the objective of this research was to foster Rimbang Sekampung Village community through the creative industry of Catri $\mathrm{N}$ Art in an effort to optimize the potencies of natural and human resources to revitalize philosophical local wisdom of Malay motif ornaments on woven gedebong as supporters of the tourism sector and creative economic development based on local wisdom. There were four motifs used in the design of woven gedebong, they were flora, fauna, natural and wajik motifs. The philosophical local wisdom values of Malay ornaments are (a) taqwa value (faith) to Allah in the motif of moon, stars, (b) harmony value in the motif of ants, ducks, flowers, fish, (c) wisdom value in the motif of birds (d) heroic value in the motif of dragon, rooster, 
(e) affection value in the motif of flora such as lilies, flowers, clove flowers, cucumber flowers, kundur flowers, set buds, dwarf florets. (f) fertility value in bamboo motifs (g) Self-Knowing value in the motif of full moon with all its variations, (h) responsibility value in the motif of keluang, and root. Based on color, there were 5 colors used in the woven gedebong, including yellow, green, red, blue, and black (Sopa, 2018:531)

This research was important to do to create employment and to improve the quality of human resources through local wisdom-based creative industry in each region to support the tourism and economic sectors and to create good quality and innovative products to produce new opportunities for souvenir industry based on local wisdom in the form of woven gedebong of Malay ornaments in supporting the development of tourism potency and fostering creative industries.

In other words, this research was conducted as an alternative solution in the Industrial Revolution 4.0 to the development of tourism sector based on the local wisdom by optimizing the potency of human and natural resources through fostering Catri $\mathrm{N}$ Art creative industry to play an active role in creating souvenirs of Medan that have local cultural values by utilizing Malay motif ornaments in woven gedebong as an effort to preserve culture and revitalize Malay local wisdom that is useful for the development of tourism potency and fostering creative industries based on local wisdom.

The development of tourism potency is an activity to improve a place by using various tourism resources to create something that is directly beneficial for the sustainable of tourism development (Mahfud, 2017: 110). The main elements of concern to support the development of tourism in tourist destinations include (a) tourism objects and attractions (b) infrastructure and (c) facilities (Subekti, 2017: 130).One of the main attractions of a tourist attraction to visit as a tourist destination in Indonesia is its cultural uniqueness. For example, cultural attractions in the form of artistic attractions, traditional ceremonies, noble values contained in an object of human work in the past are one of the targets of foreign tourists to remain loyal to visit Indonesia. (Hermawan, 2017: 4).

\section{Literature Review}

The development of tourism potency is an activity to improve a place by using various tourism resources to create something that is directly beneficial for the sustainable of tourism development (Mahfud, 2010: 110). The main elements to support the development of tourism in tourist destinations include (a) tourism objects and attractions (b) infrastructure and (c) facilities (Subekti, 2017: 130). One of the main attractions for a tourist to visit Indonesia as a favorite destination is its cultural uniqueness. For example, cultural 
attractions in the form of artistic, traditional ceremonies, noble values contained in an object of human work in the past (Hermawan, 2017: 4). In this research, the development of tourism potency as strategy to attract tourists visit North Sumatra especially Binjai is by revitalizing the woven gedebong product with the Malay motif ornament as a regional superior product with a unique souvenir of cultural value..

Besides, it is also necessary to develop the creative industry to create souvenirs of local cultural value as an attraction for tourists to remain loyal to visit North Sumatra. One of the creative industries that can be fostered is Catri $n$ Art, Rimbang Sekampung Village. In related to this case, the concept of the development of creative industry in this research is to provide guidance and counseling to creative industry of Catri $\mathrm{N}$ Art to be able to become independent entrepreneurs by exploring the potency of regional creativity in the use of regional superior products such as woven gedebong in the Rimbang Sekampung village. Thus, the development of Catri N Art to become an independent creative entrepreneur can optimize communities' creativity, improve the economy and also develop tourism potency (Citra, 2017:33).

In other words, this research developed the community of Rimbang Sekampung Village especially the creative industry Catri $\mathrm{N}$ Art to produce gedebong woven as a regional superior product by applying the philosophy of Malay motif ornaments. This development was conducted to optimize the tourism potency, foster epreneurship, and increase the economy of the community.

The value of the Malay style applied to woven is the value of the wisdom of the philosophy of the Malay community. The philosophical values of the Malay motif ornamentsrefer to the nature of the origin of the object or creature that is used as a pattern and combined with the beliefs and culture of the Malay people that are related to the noble value of Islam. (Malik, 2017:97)

In general, the values of the local wisdom of philosophy contained in Malay motif ornaments are (a) the value of faith to Allah in the motif of the crescent moon, stars, (b) the value of harmony in the motif of ants, ducks pulang petang, flowers hugging leaves, brood fish. (c) the value of Wisdom in serindit bird motif that are posted as a symbol of Malay wisdom (d) the value of heroism in the motif of fighting dragons, cup dragons, eagle grabbing, roosters. (e) thevalue of affection in almost all floral motifs such as lilies, flowers, clove flowers, cucumber flowers, kundur flowers, set buds, dwarf florets. (f) the value of fertility in bamboo shoots with all forms of variation. (g) the values of self-knowing in full moon patterns, bracken ferns with all their variations, and some shades of cloud. (h) the value of responsibility in elbow patterns, intertwined roots, etc. (Maulia, 2015:7) 
Motifs can be developed so that the values of local wisdom are not lost and extinct (Kartini, 2014:7). One of them is the development of temple based ornamental teaching materials in Central Java. Various identified ornaments can be used as references in the construction of teaching materials, according to learning needs that can be developed including geometric, plant, animal, and human motifs. These various motives can specifically be used as material for study and appreciation. In addition, it can also be used as a reference in developing creative teaching materials, when students make temple-based ornament designs (Hartanti, 2014:531).

According to Malay ethnic, the meaning and philosophy of each ornament is to increase people's interest of this ornament and also to spread the values of Islamic teachings. Because in the past every craftsman was taught to make or imitate ornaments motif, then explained the meaning and philosophy contained in the ornament. Thus, they can understand it more deeply and place it in accordance with the philosophical meaning and are governed by the customs of the local community (Wahyuni, 2017:117)

The development of tourism potency in Catri N Art was conducted by utilizing the potency of the creativity of the surrounding community by exploring the cultural values of regional superior products. The creative industry of Catri $N$ Art is a place that can be developed and fostered to improve the economy of the local community. The typical and unique souvenirs that will be sought from this creative industry are woven gedebong of Malay motif ornament products such as bag, pencil case, Kleenex box, cookie box, slippers, ashtray, skewerso that the Malay motif ornament of woven gedebong can be used as unique souvenirs of Rimbang Sekampung Village and also as an attraction for tourists to visit and learn the values of local wisdom that exist in the community of Rimbang Sekampung Village.

Thus, it is hoped that Rimbang Sekampung Village can develop tourism potency and improve the economy of the surrounding community. And in the future, the creative industry of Catri N Art can be used as a place for the development of tourism potency based on local wisdom, the development of community productivity and creativity to become independent entrepreneur as a form of real action to revitalize and preserve local wisdom values, so that government program in the form of developing tourism potencies based local wisdom can run well. This development can be done through the optimization of potency, appreciation, and community participation to local culture by practicing traditional ways of managing human resources so as to provide benefits to the sustainable of tourism sector. (Richard, 2003:7) 


\section{Research Method}

This research used a qualitative descriptive approach with a field case study method located in Rimbang Sekampung Village especially at the Creative industry of Catri $\mathrm{N}$ Art. Catri N Art in Rimbang Sekampung Village is located at Jalan Belimbing No. 16 A, West Binjai District, Binjai.

The population of this research was the community of Rimbang Sekampung Village, Binjai. The selection of sample was conducted by applying purposive sampling technique. Based on this method, the selection of the research sample consists of two stages, namely: First step was to select the people of Rimbang Sekampung Village who become sample. At this stage, the selection of sample was based on the creative potency in the field of woven arts owned by the community and the desire for entrepreneurship. Second stage was to choose a creative industry that can be fostered and developed to create souvenirs of local cultural value in Desa Rimbang Sekampung village.

Data was collected through documentation, field observation, and interview. The procedures for collecting data in this research are (a) Documentation in the form of photographs of ornaments from several Malay buildings in the city of Medan and the realization of research activities (b) Field observations in the form of researchers to the field directly observe the place of Rimbang Sekampung Village (place), and communities in Rimbang Sekampung (people). The participants of this research were the owner and the founder of Catri N Art Catur Meilono (54 years), and some of his employers are Catri Adiyati Purbadari (28 years), Jaka Arif Pratama (34 years), Hariyanto (40 years), Erlina (37 years). (c) Interviews the informant who someone has expertise and knowledge about Malay culture was Drs. Fahrizal Nasution.

The result of the research was the woven gedebong which applyied Malay motif ornament as an effort to revitalize the philosophy of Malay ornament and as an innovative way to develop woven products which had the value of selling local culture by using Photoshop CS6 application Software in designing Malay motif ornament. The following is the research scheme about the implementation of research on the stages for conducting research:

Based on the scheme of research design above, the activities in each stage consist of research objectives, literature study, problem identification, data collection, data analysis, results of data analysis. The activities were carried out at each stage as follows:

1. The target and the objective of the research is to provide guidance to the Creative industry of Catri N Art in optimizing the potencies of Human and natural resources 


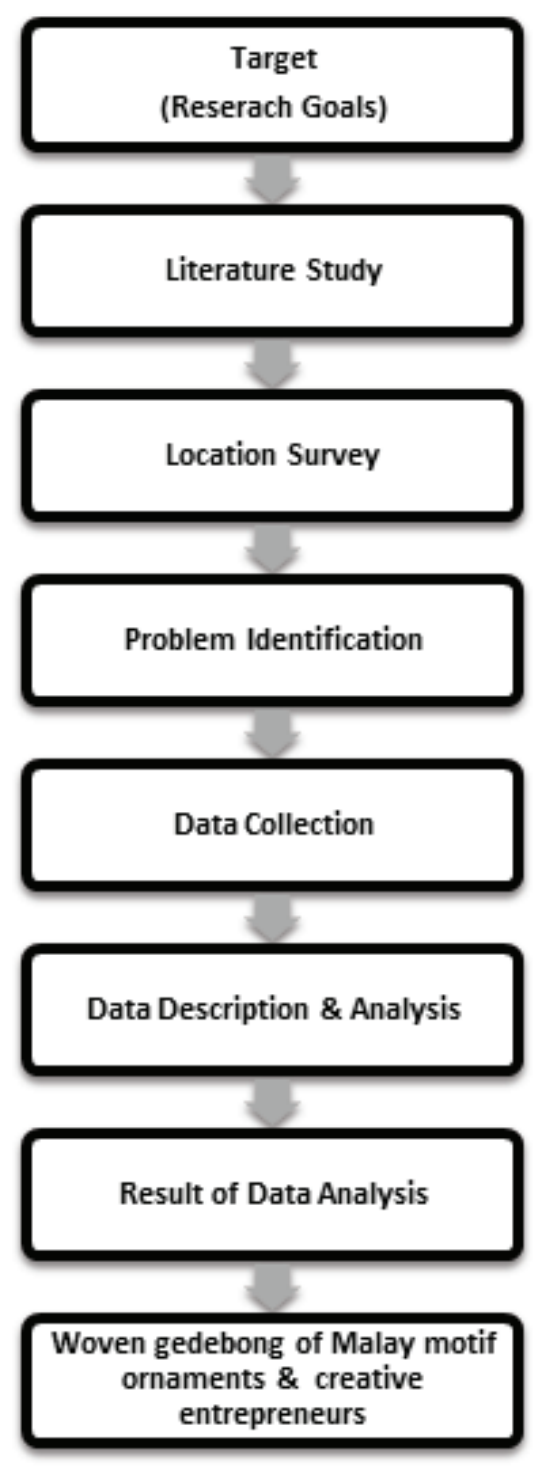

Figure 1: Research Design Scheme.

of Rimbang Sekampung Village in producing superior products of the Malay motif ormanets in the woven gedebongas an effort to implement solutions to problems in the field namely product production and marketing systems that have not been optimal in an effort supporters of tourism and creative industries based on local wisdom, resulting in innovative woven and selling value of local culture.

2. The Collection of literature (library study) is collecting information and knowledge about research in the form of a process of fostering cerative industry in producing souvenirs of local cultural value as an effort to support tourism and creative industries based on local wisdom. 
3. Location Survey was conducted to find and select creative industry that can be fostered to develop the potencies of tourism and creative industries based on local wisdom.

4. Problem identification was identifying problems found in the field related to the production and marketing system of woven products that have not been optimal in the Catri N Art creative industry

5. Data collection is collecting data with field observations, photo documentation and interviews related to research problems.

6. Data Descriptions and analysis to provide an overview of how solutions are implemented starting with identification, classification, analysis, interpretation of data and making conclusions.

7. The results of the analysis of data in the form of data will be in the form of a Malay ornamental woven model in an effort to revitalize Malay ornamental motif philosophy as a form of developing woven products to innovate by using Photoshop CS6 Software applications in designing ornamental patterns so as to develop products that are innovative and value for selling local culture.

\section{Result and Discussion}

\subsection{The creative industry of Catri N Art, Rimbang Sekampung vil- lage}

The creative industry of Catri N Art is located at Jalan Belimbing No. 16 A, West Binjai District, Binjai, Rimbang Sekampung Village. Catri N Art has 4 employers who work to make the woven bamboo. Previously, this creative industry produces the woven in made of bamboo, but unfortunately, this product is not able to develop well in the market as the sale value souvenir, so the researcher offered the solution to optimalisation the potencies of society in Rimbang Sekampung village especially in the creative industry of Catri N Art to produce the woven in made of gedebong based on loacal wisdom of Malay that apply the Malay motif ornament.

The informant of this research isthe owner and the founder of Catri N Art, Rimbang Sekampung Village Mr. Catur Meilono (54 years), and some of his employers are Catri Adiyati Purbadari (28 years), Jaka Arif Pratama (34 years), Hariyanto(40 years), Erlina (37 years). 
These are some following figures shows Catri $\mathrm{N}$ Art creative industry, Rimbang Sekampung Village:

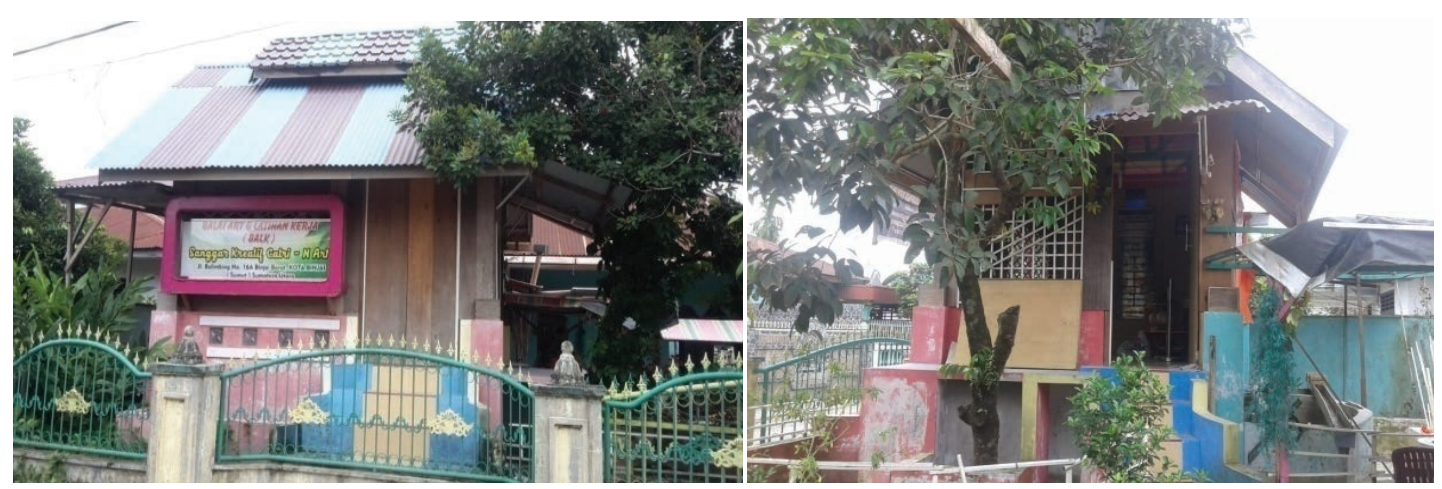

Figure 2: Catri N Art, Rimbang Sekampung Village.

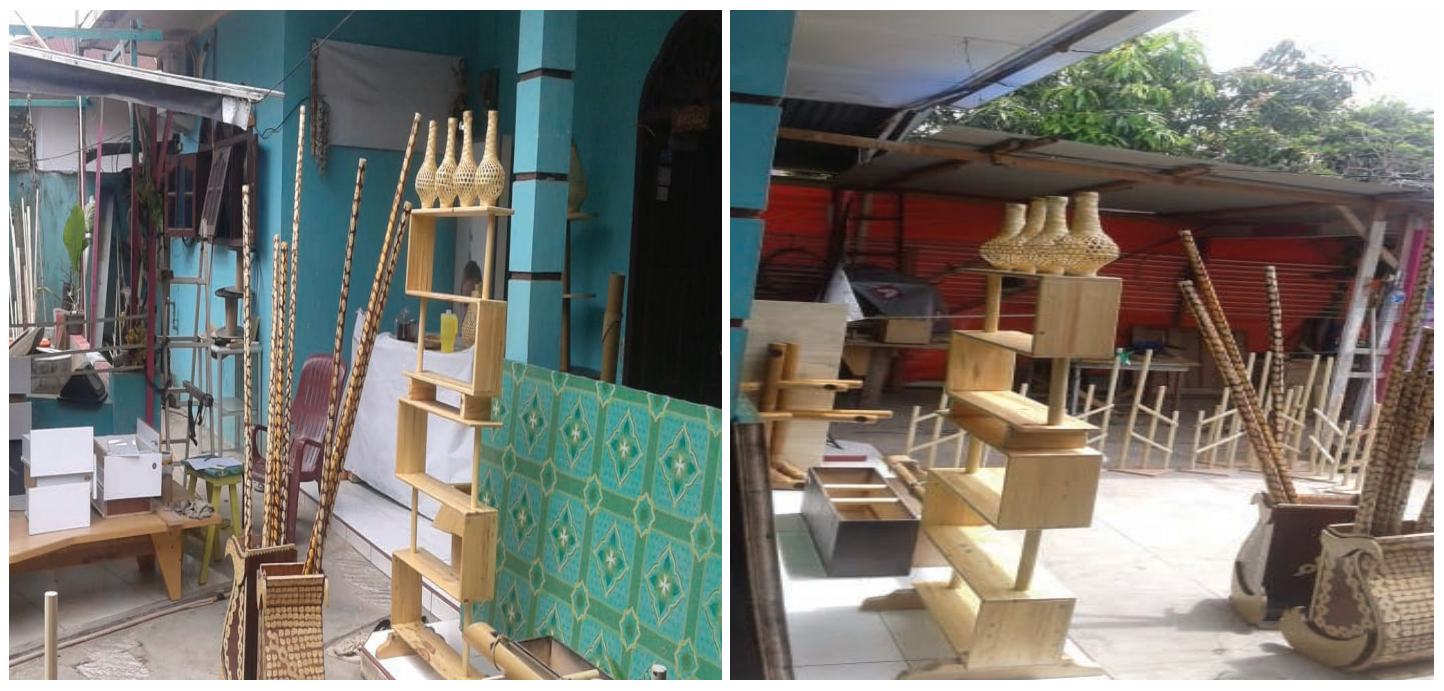

Figure 3: Products of Catri N Art, Rimbang Sekampung Village.

\subsection{Optimimalizing potencies of Rimbang Sekampung village}

The research was conducted with the optimalization and development of Catri N Art creative industry in the realization of the production, management, and marketing systems to create the woven gedebong based on Malay motif ornaments.

In production system, the societies in Rimbang Sekampung village especially in Catri $\mathrm{N}$ Art creative industry were provided with materials, tools and medium to carry out entrepreneurial activities. They are also taught the way to produce woven with the culture sale value such as the way to make woven gedebong based on Malay motif 
ornament which applying Malaylocal wisdom. These are some following figures show the materials used to make woven gedebong base on Malay motif ornaments.
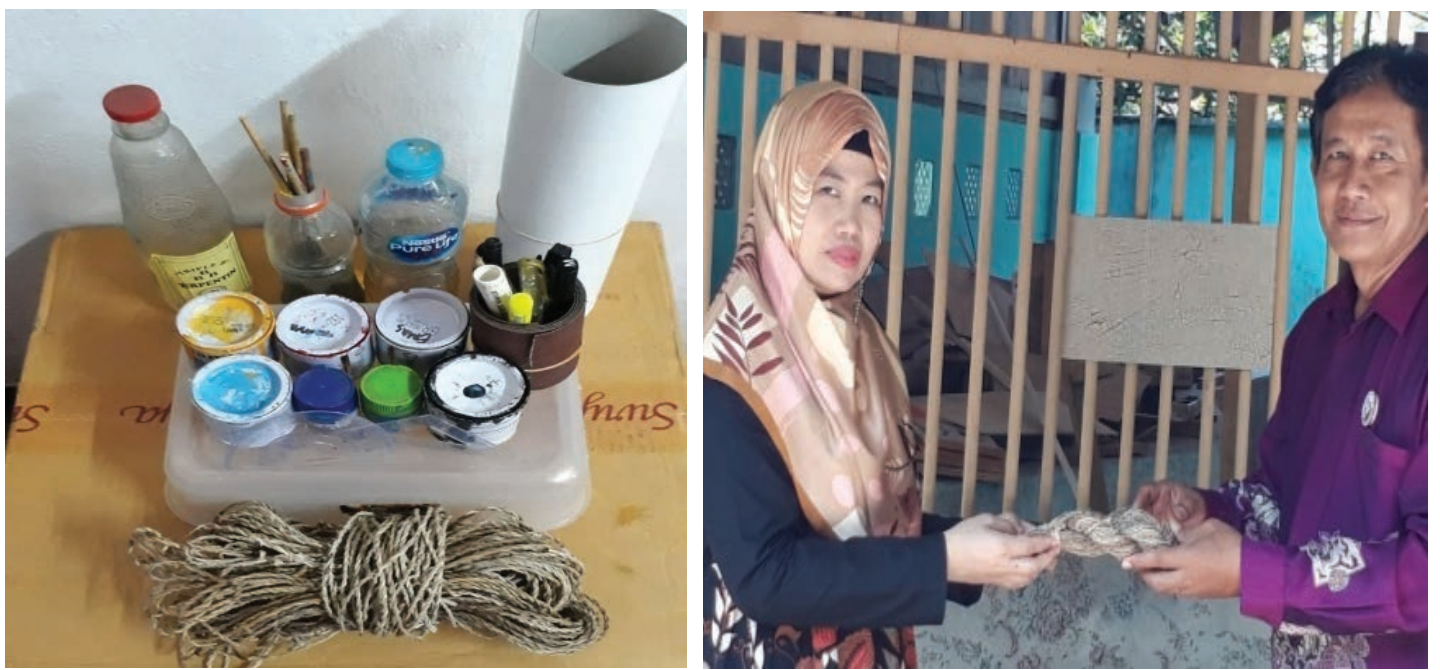

Figure 4: Materials of Woven Gedebong base on Malay Motif Ornaments.

Then, the societies in Catri N Art of Rimbang Sekampung village were also coached and taught to produce woven using banana stem or gedebong base on Malay motif ornaments. These are some following figures of making banana stem or gedebong used for making woven.

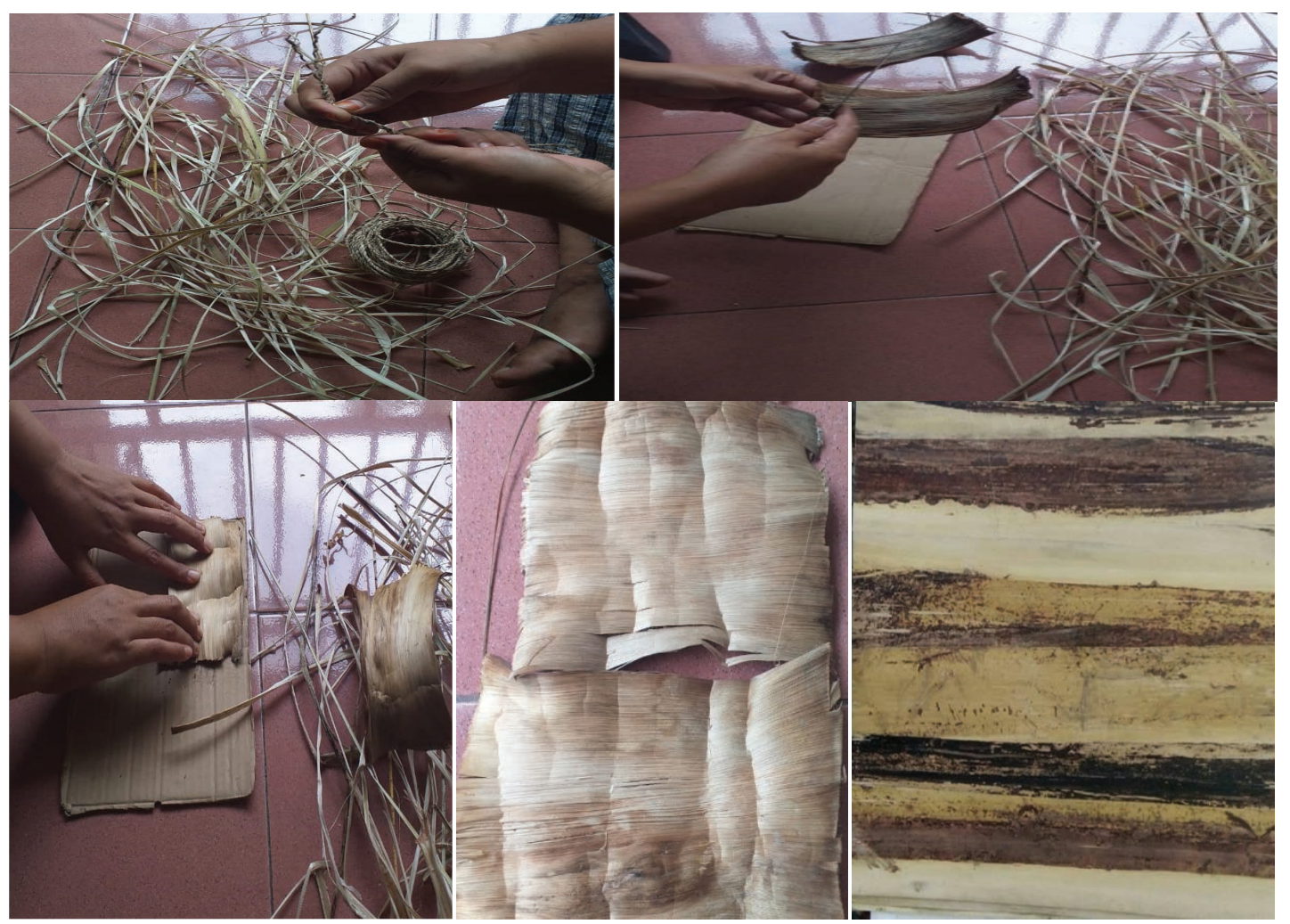

Figure 5: Production Process of Making Woven from Gedebong. 
The society in Rimbang Sekampung village especially who work in Catri N Art were taught to use gedebong to make woven base on malay local wisdom that is Malay motif ornament.

In management system, the entrepreneur in Catri N Art are couched and taught to manage the organization by creating a system of labor division.

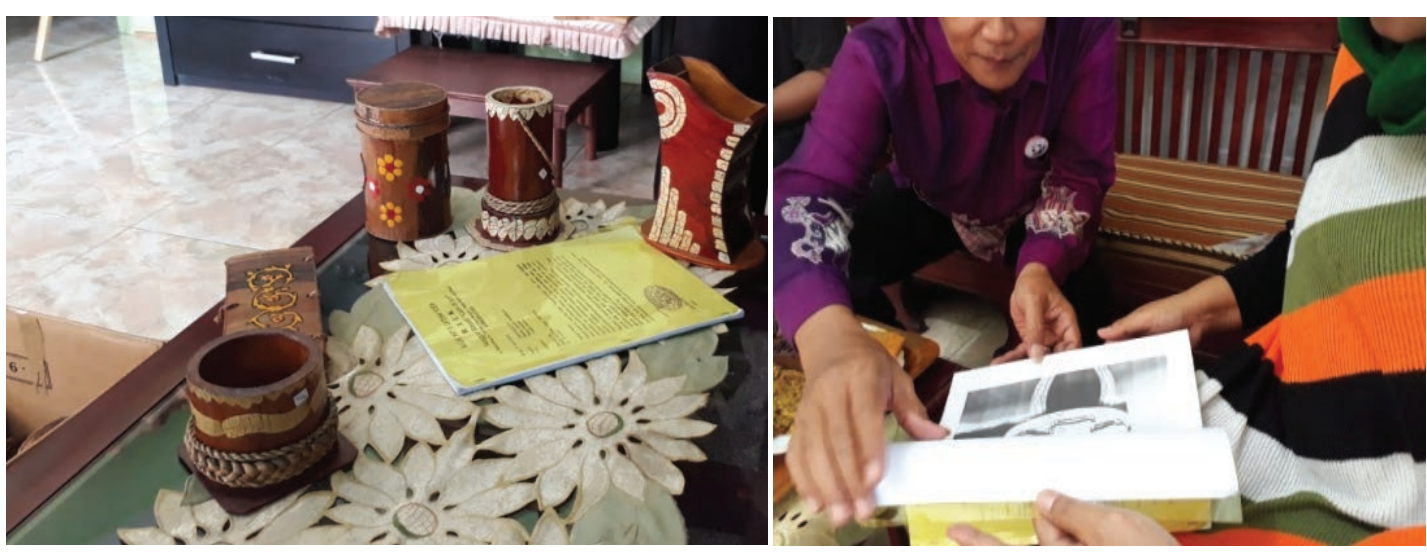

Figure 6: Management Process of Labor Division in Catri N Art.

In marketing system, they are taught to promote their products through social media, namely instagram and Facebook. In other words, the optimalization and development processes were carried out from all systems of production, management and marketing. This is the following figure of name card to promote the creative industry Catri N Art, Rimbang Sekampung village:

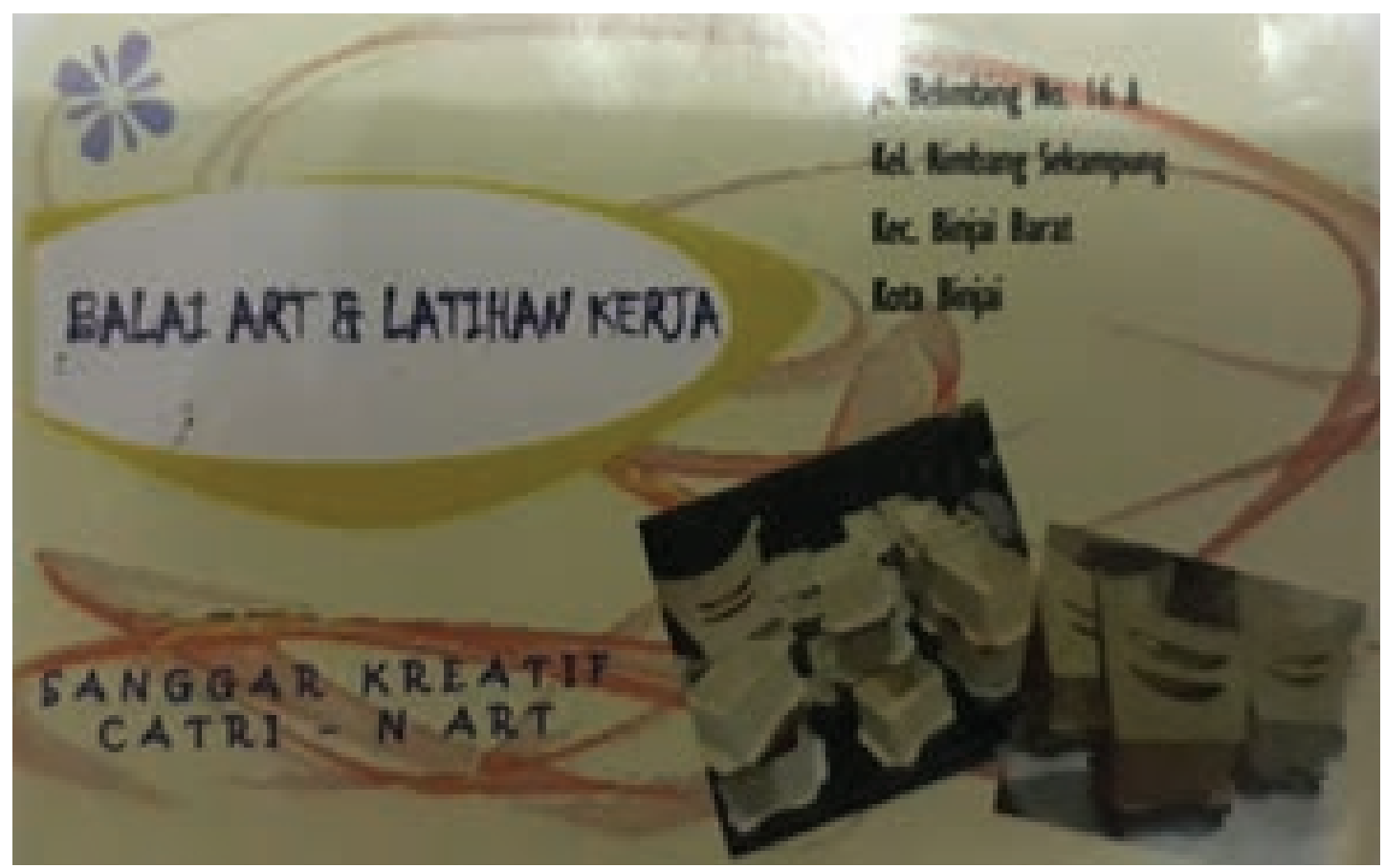

Figure 7: Name Card to Promote Catri N Art Creative Industry, Rimbang Sekampung. 


\subsection{Woven Gedebong base on Malay motif ornament}

Woven gedebong were produced by Catri N Art creative industry Rimbang Sekampung village by applying the Malay motif ornaments. The Malay motif ornaments used in the woven gedebong of this research are flora, fauna, nature, anad wajik. The Malay motif ornaments were applied in the woven gedebong in the form of bag, pencil case, tissue box, cookie box, slipper, ashtray, skewer.

There were some philosophical colors used in the Malay motif Ornaments in the design of woven gedebong. These colours were used to show the symbolic meanings for Malayethnic. Malay ethnic considered these five colors that are having meanings applied in everyelement of the object such as custom clothes, custom houses, and ornaments.Color for Malay ethnic is a symbol that can distinguish one person in their lives. Color can also signify compliance. The colours of ornaments used in the woven gedebong of this research are yellow, red, white, gold, and black. Yellowsymbolizes the holiness for Malay people. The yellow means Malay king who has power and can only be used by the royal family.Red symbolizes a sign of brotherhood and courage. Malay ethnic use red as the spirit of Malay community to defend their warfare.White symbolizes chastity and mourning. Blue symbolizes strength in the river and the ocean and also designated for the kingdom. Green symbolizes fertility and prosperity. Black symbolizes of courage and always used by commanders. Goldsymbolizes of glory and grandeur and also used by the king's power.

There werealso four motifs used in the design of woven gedebong, they were flora, fauna, natural and wajik motifs. Firstly, flora motif ornaments are from flowers, florets, leaves, fruits, roots. Secondly, fauna motif ornaments are from poultry animals such as bird, duck, chicken, reptile animals such as snake, dragon, wild animals such as lion, tiger, insects such as bee, butterfly, grasshopper, aquatic animals such as fish, eel. Thirdly, outer space (nature) motif ornaments are from moon, star, sun, cloud. And lastly, wajik motif ornaments are from the alquran ayats.

The philosophical local wisdom values of Malay ornaments are the values of taqwa (faith) to Allah, harmony, wisdom, heroic, affection, fertility, self-knowing, and responsibility. The result showed that the optimization of Catri $N$ Art potency to produce woven gedebong based on Malay motif ornaments can be useful to revitalize the Malay philosophy of local wisdom values and also to increase creative industry. These are some following figures of woven gedebong based on Malay motif ornamnets as the result of the research: 


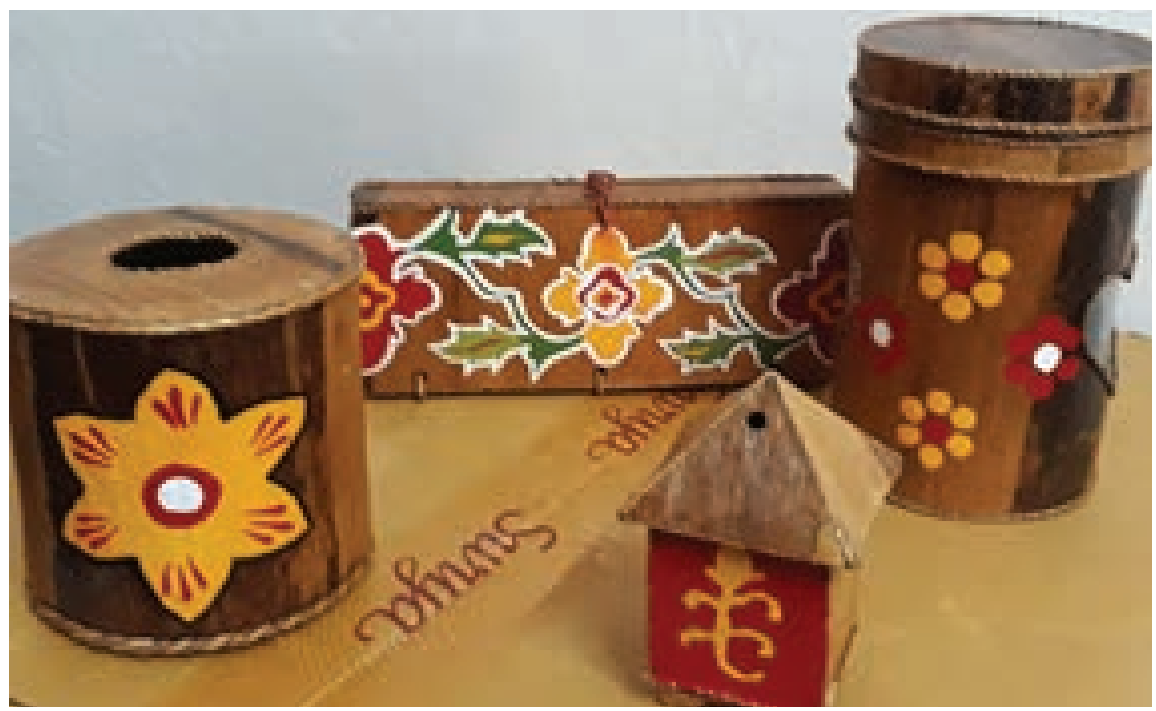

Figure 8: Malay Motif Ornament symbolyzes Flora.

In the Figure 8 uses flora motif ornaments. These flora motif ornaments are applied on the woven gedebong of tissue box, pencil case, cake box, and skewer box. These flora motif ornaments have philosophical meaning that relate to the symbol of love, purity, sincerity and subtlety of character, friendship, and brotherhood. In terms of color, the meaning of red for Malay people as a color means brotherhood and courage. The meaning of yellow for Malay people as a symbol of holiness. This yellow color in the kingdom of Malays still in power can only be used by the royal family. Green color for Malay people as a color means fertility and prosperity. And the white color for Malay people as a color of chastity and in white traditional dress is considered a sign of misfortune.

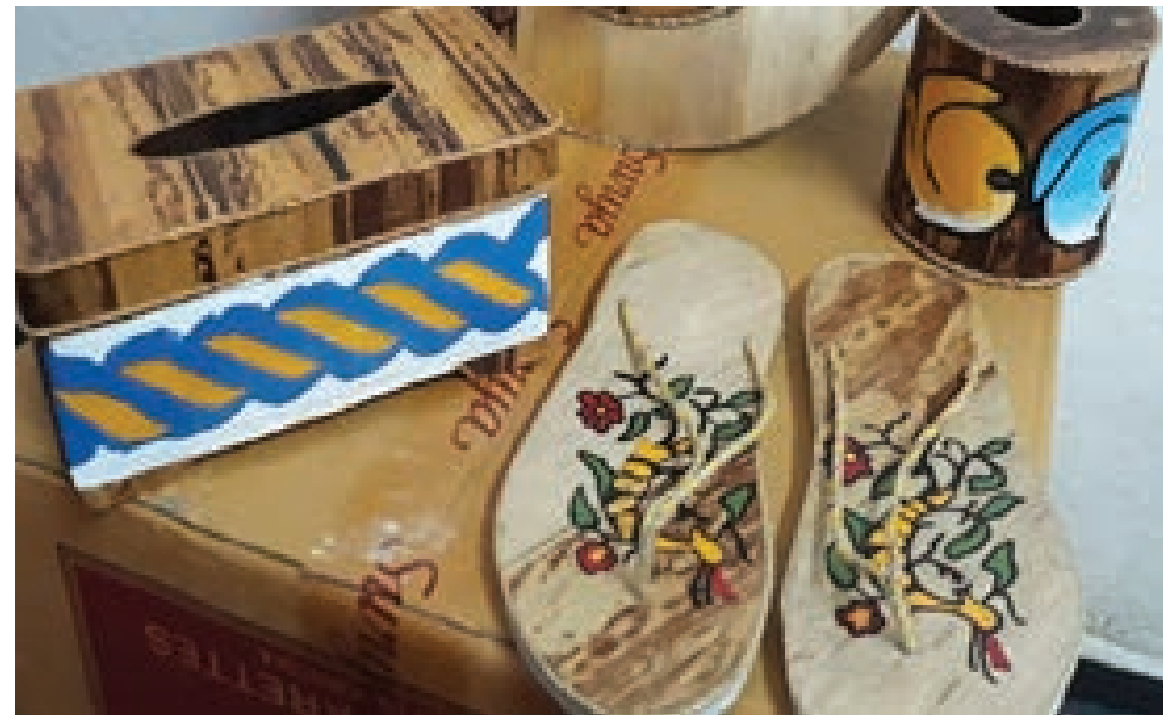

Figure 9: Malay Motif Ornament Symbolyzes Fauna. 
In the Figure 9 uses fauna motif ornaments. These fauna motif ornaments are applied on the woven gedebong of slipper, tissue box, and hat. These fauna motif ornaments have philosophical meaning that relate to with courage and wisdom. In terms of colors are namely blue, red, yellow, green and white. The meaning of blue for Malay people as color means strength. In the Malay kingdom, blue is usually used by the Malay kingdom. The meaning of red for Malay people as a color means brotherhood and courage. The meaning of yellow for Malay people as a color means purity. This yellow color in the kingdom of Malays still in power can only be used by the royal family. And green for Malay people as a color means fertility and prosperity. And the white color for Malay people as a color of chastity and in white traditional dress is considered a sign of misfortune.

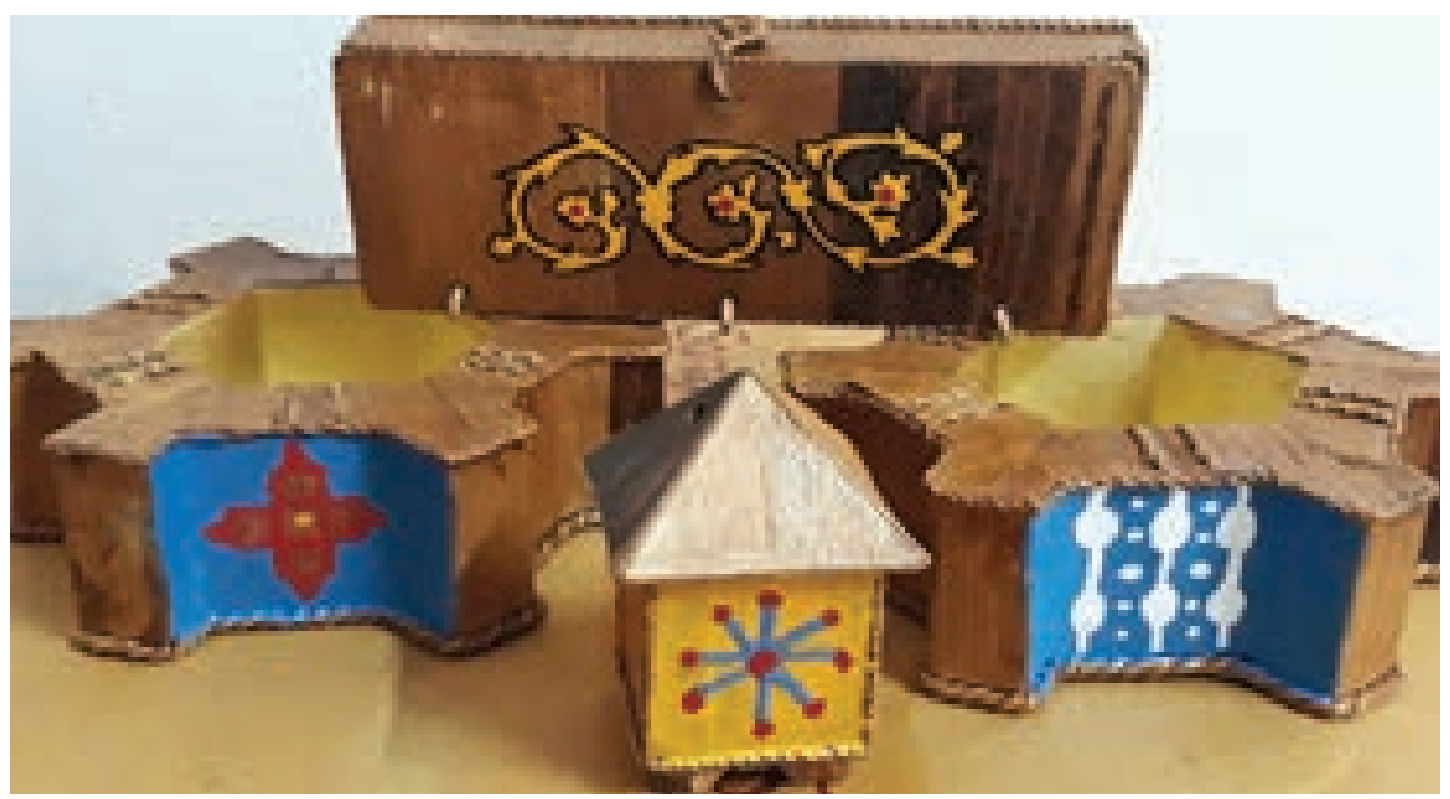

Figure 10: Malay Motif Ornament symbolyzes Nature.

In the Figure 10 uses outer space (nature) motif ornaments. These nature motif ornaments are applied on the woven gedebong of pencil case, skewer box and ashtray. These nature motif ornaments have philosophical meaning that relate to love and justice. In terms of colors are namely white, blue, red, and yellow. The meaning of white for Malay people as a color of chastity and in white traditional dress is considered a sign of misfortune. The meaning of blue for Malay people as color means strength. In the Malay kingdom the blue color is usually used by the kingdom. The meaning of red for Malay people as a color means brotherhood and courage. And the meaning of yellow for Malay people as a color means purity. This yellow color in the kingdom of Malays still in power can only be used by the royal family. 


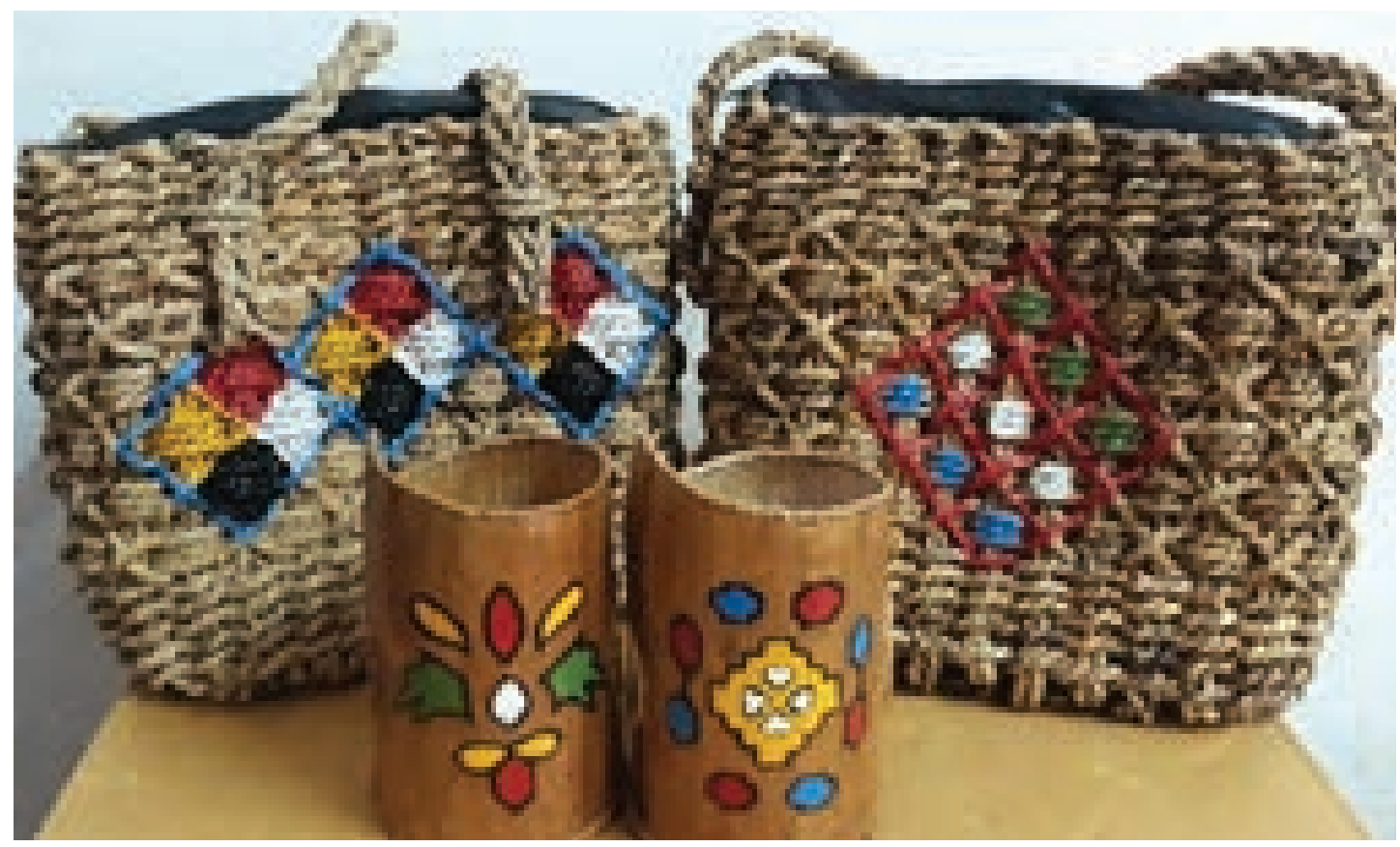

Figure 11: Malay Motif Ornament symbolyzes Wajik.

In the Figure 11 uses wajik motif ornaments. These nature motif ornaments are applied on the woven gedebong of bag and office stationery box. These wajik motif ornaments have philosophical meaning that relate to the nature of Allah SWT who is Most Gracious and Most Knowledgeable. In terms of the colors are namely red, black, yellow, white and blue. The meaning of red for Malay people as a color means brotherhood and courage. Black as color means strength. This color is always used by the commander and the commander. The meaning of yellow for Malay people as a color means purity. This yellow color in the kingdom of Malays still in power can only be used by the royal family. The white color for Malay people as a color of chastity and in white traditional dress is considered a sign of misfortune. And the meaning of blue for Malay people as color means strength. In the Malay kingdom, blue is usually used by the Malay kingdom.

\section{Conclusion}

Based on the above discussion, the discussion can be concluded as follows:

1. Malay ornaments has four motifs used in the design of woven gedebong, they are flora, fauna, natural and wajik motifs. Firstly, fllora motifs ornaments are from flowers, florets, leaves, fruits, roots. Secondly, faunamotifs ornaments are from poultry animals such as bird, duck, chicken, reptile animals such as snake, dragon, wild animals such as lion, tiger, insects such as bee, butterfly, grasshopper, aquatic 
animals such as fish, eel. Thirdly, outer space such as moon, star, sun, cloud, and lastly, Wajiksuch as the alquranayats. The philosophical local wisdom values of Malay ornaments are the values of taqwa(faith) to Allah, harmony, wisdom, heroic, affection, fertility, self-knowing, and responsibility.There were some philosophical colors used in the Malay motif Ornaments in the design of woven gedebong. These colours were used to show the symbolic meanings for Malayethnic. The colours of ornaments used in the woven gedebong of this research are yellow, red, white, gold, and black.

2. The process of the creative industry development Catri N Art, Rimbang Sekampung village is conducted by giving entrepreneurship lessons such as coaching and teaching in production, management and marketing aspects. In production aspect, the entrepreneurs of Catri $\mathrm{N}$ Art are provided with materials, tools and medium to carry out entrepreneurial activities. They also are taught the way to produce goods with the sale value such as the way to make woven gedebong based on Philosophical Malay motif ornament which applying Malaylocal wisdom and their creativity. In management aspect, the entrepreneur is couched and taught to manage the organization by creating a system of labor division. In marketing aspect, they are taught to promote their products through social media, namely instagram and Facebook. In other words, the empowerment and foster process was carried out from all types of production, management aspects and marketing aspects. This process depends on the target and objectives to be achieved from each of the reporting programs implemented.

3. The research shows the woven gedebong in the model of souvenirsare drawn base on the local wisdom of Malay culture by the society of Rimbang Sekampung village especially in Catri N Art Medan. In other words, this souvenir product can be promoted as a regional superior product or the work of the creativity of the society in Rimbang Sekampung village especially in the small group enterprise of Catri N Art.

\section{Acknowledgements}

The researcher would like to express his/her gratitude to the Ministry of Research and Technology and Higher Education of the Republic of Indonesia (KEMENRISTEKDIKTI) for its funding of this research. 


\section{References}

[1] Citra, I. P. A. (2017). StrategiPemberdayaan Masyarakat untukPengembanganEkowisata Wilayah Pesisir di KabupatenBuleleng. JurnalllmuSosial dan Humaniora, 6(1), 31-41.

[2] Hartanti, G., \&Nediari, A. (2014). PendokumentasianAplikasiRagamHiasBudaya Bali, SebagaiUpayaKonservasiBudayaBangsaKhususnya pada Perancangan Interior. Humaniora, 5(1), 521-540.

[3] Hermawan, H. (2017). PengaruhDaya Tarik Wisata, Keselamatan, Dan SaranaWisataTerhadapKepuasan Serta DampaknyaTerhadapLoyalitasWisatawan: Studi Community Based Tourism di GunungApiPurbaNglanggeran. JURNAL MEDIA WISATA: WahanalnformasiPariwisata, 15(1).

[4] Juliana, J., Fatimah, F., \&Yanti, A. (2018, April). Empowering MedanArt CommunityThroughDeveloping GraffityWriting as CreativelndustryModel (The LocalWisdom of MalayDeli). In AICLL: AnnuallnternationalConference on Language and Literature (Vol. 1, No. 1, pp. 204-211).

[5] Juliana, J., Fatimah, F., \&Apriliyanti, A. (2018). Empowering and Fostering Creative Industries Entrepreneurs Based on Local Wisdom of Malay Deli. KARSA: Journal of Social and Islamic Culture, 26(2), 215-250.

[6] Juliana, J., Fatimah, F., \&Apriliyanti, A. (2018). PembinaanPenulisanGrafitiSebagaiWadah Creative Entrepreneur BerbasisKearifanLokalBudayaMelayu Deli. JurnallImiah Lingua Idea, 9(2), 129-143.

[7] Kartini, A. (2014). AnalisisPenerapanOrnamenBernuansaMelayuDitinjau Dari Bentuk Dan Warna Di Kota Medan(Doctoral dissertation, UNIMED).

[8] Mahfud, T., Mulyani, Y., \&Setyawati, R. (2017). PengembanganPariwisataBerbasisKomunitas: StrategiKomunitas Foodies DalamPengembanganWisataKulinerDi Balikpapan. Prosiding SNITT POLTEKBA, 2(1), 105-117.

[9] Malik, A., \&Mulyono, S. E. (2017). Pengembangankewirausahaanberbasispotensilokalmelaluipemberdayaanmasyarakat. Journal of Nonformal Education and Community Empowerment, 1(1), 87-101.

[10] Malik, A., Effendy, T., Junus, H., \&Thaher, A. (2003). Corak dan RagiTenunMelayu Riau. AdicitaKarya Nusa, Yogyakarta.

[11] Maulia, R. (2015). WisataBudayadalamTradisiTenun di KecamatanMempuraKabupatenSiak. Jurnal Online Mahasiswa (JOM) BidangllmuSosial dan IImuPolitik, 2(2), 1-11. 
[12] Richards, G., \& Hall, D. (Eds.). (2003). Tourism and sustainable community development (Vol. 7). Psychology Press.

[13] Samadi, Z. H., \&Qamaruzzaman, N. (2009, July). The Revitalization of Community Centre. In National Conference of Research Knowledge \& Intellect Application.

[14] Sopa, M. (2018). Local Wisdom in the Cultural Symbol of Indonesian Traditional House. KnE Social Sciences, 3(4), 524-531.

[15] Subekti, P., \&ruchiatNugraha, A. (2017, July). Tourism Communication Strategy DisbudparPangandaran In Developing Culture And Arts In Pangandaran. In Annual Conference of Communication, Media and Culture (ACCOMAC) (Vol. 1, No. 1, pp. 130-133).

[16] Utara, B. P. S. P. S. (2010). Sumatera Utara dalamAngka 2010. Badan Pusat StatistikProvinsi Sumatera Utara, Medan.

[17] Wahyuni, A., \& Pertiwi, S. (2017). EtnomatematikadalamragamhiasMelayu. Math Didactic: Jurnal Pendidikan Matematika, 3(2), 113-118. 